\title{
UK Macro-Algae Biofuels: A Strategic Management Review and Future Research Agenda
}

\author{
Per Gegg ${ }^{1}$ and Victoria Wells ${ }^{2, *}$ \\ 1 Durham University Business School, Durham University, Mill Hill Lane, Durham, DH1 3LB, UK; \\ per_gegg@yahoo.co.uk \\ 2 Sheffield University Management School, Sheffield University, Conduit Road, Sheffield, S10 1FL, UK \\ * Correspondence: victoria.wells@sheffield.ac.uk; Tel.: +44-0-114-222-3271
}

Received: 25 June 2017; Accepted: 25 July 2017; Published: 31 July 2017

\begin{abstract}
Macro-algae is increasingly gaining attention as a potential feedstock for biofuels and as a potential alternative fuel for aviation. Technological aspects are showing promise, and being examined more widely. This paper uses a strategic management perspective to complete an initial macro-environmental scan of the potential opportunities and threats to a seaweed biofuels industry. This is in response to calls to look beyond technological aspects, and highlights the importance of social acceptance. It is clear that very little is known about the potential economic, social, environmental and political/legal issues that might arise in the development of this industry. While we can look at the development of other, more established renewable technologies and seaweed industries away from the UK to highlight potential issues this does not give us a clear picture. Further research is needed to ensure that a proactive approach is used to research and inform stakeholders who will affect the further technological development and commercialization of the industry.
\end{abstract}

Keywords: macro-algae; seaweed; biofuel; aviation; strategic management; macro-environment; PESTEL; social acceptance; policy

\section{Introduction}

With the ever-increasing threat of energy (in)security, oil price volatility and growing political pressure to reduce greenhouse gas (GHG) emissions, the need to develop a sustainable and economically viable alternative to traditional fossil-based fuels and to develop deep decarbonization strategies has never been greater [1-3]. While progress has been made in the development of renewable and clean methods for producing heat and power, transportation remains largely dependent on liquid hydrocarbon fuels [1]. Indeed, liquid fuels will remain prevalent in transportation for several decades, particularly in commercial aviation and road haulage where energy demands prohibit electrification [2,4]. In terms of sustainable liquid fuel, biofuels are at the forefront due to their ease of manufacture and the fact that they can be integrated directly into existing infrastructure while reducing carbon emissions and strengthening domestic fuel security $[1,5]$. In the last 20 years biofuel production has grown substantially because of aggressive nationally-led incentives and funding programmes initiated in several Organisation for Economic Co-operation and Development (OECD) countries. Due to the rapid expansion of production there are now established commercial markets for ethanol and biodiesel in Europe, North America, South America, Asia, Asia Pacific and Africa [6]. Ethanol and biodiesel are predominantly supplied to the road transport sector and used as an additive or an alternative to gasoline and diesel. In recent years new transportation sectors have shown considerable interest in using biofuels as an alternative fuel - the most notable being commercial aviation [2]. Research notes that renewable jet fuel production is increasing, in line with targets set by the International Civil Aviation Organisation (ICAO) and could contribute significantly to the reduction of aviation-related GHG emissions [7]. It has 
been noted [8] that there are currently no significant supplies of sustainable aviation fuel worldwide and establishing a supply chain for this is a major challenge.

Although biofuels have several advantages in terms of emissions savings, fuel security, rural economic development and compatibility with incumbent infrastructure $[9,10]$, they have attracted significant controversy from environmental groups, the media and academics because of their association with unsustainable farming practices, negative land use change effects and impacts on the food supply $[1,10,11]$. These issues are predominately related to so-called 'first-generation biofuels' which are typically derived from edible feedstocks and/or feedstocks grown on land which could otherwise be used for food. First generation feedstocks include vegetable oils and corn sugar [12]. Although some first-generation biofuels are not damaging to the environment, governments are de-incentivizing first-generation biofuels in favour of fuels derived from non-edible, non-food feedstocks and/or feedstocks. These have less impact on the food supply and land-use change and are cheap and abundant. This group of biofuels is termed 'second generation biofuels' or 'advanced biofuels' and includes fuels that are derived from feedstocks like aquatic biomass, woody biomass, agricultural and forest residues and municipal solid waste [6,12]. Some [11] even describe algae biofuel as a third-generation biofuel. Within the UK second generation and advanced biofuels are double counted within the Renewable Transport Fuels Obligation (RTFO) and similar energy policy frameworks exist in OECD countries including the U.S., Denmark, Holland, Sweden, Norway and Germany. In response to these policy changes, the commercial biofuel industry is actively investigating advanced production methods, however there are no commercially operating biofuel facilities which have successfully utilized these advanced biomass feedstocks to produce sustainable transportation fuels at a significant commercial level.

A biomass feedstock which has received a significant level of interest in recent years is macro-algae [13]—-more commonly referred to as seaweed [14]. Seaweed first attracted the attention of the biofuel industry in the 1970's because of their relatively high rates of growth [14,15]. However, despite early optimism for the feedstock, there has been very little research in the way of commercial advances in the field [14]. This is even though some academics strongly support the view that commercially farmed seaweed could be developed into a sustainable biofuel feedstock. This would be capable of supplying a biofuel market, particularly in countries such as the UK which have extensive coastlines $[14,16,17]$. However, a considerable number of uncertainties surrounding all aspects of seaweed production for biofuels still exist [14,16-18]. Indeed, experts remain uncertain about the optimal methods of cultivation, harvesting, storing and processing of seaweed for the specific purpose of producing biofuels [14]. There is a growing amount of research and development in this area providing more certainty about the optimal methods and processes in using seaweed. However, there are currently only limited commercially operating projects generating biofuels from seaweed. This is in comparison to a range of organisations that are using micro-algae on a commercial basis including BioFuel Systems-Blue Petroleum (http:/ / www.biopetroleo.com), AlgaEnergy (http:/ / www.algaenergy.es), Muradel (http:/ / www.muradel.com/contactus.asp) and Algae.Tech (http:/ / www.algaetec.com.au). One organisation is currently using macro-algae to produce biofuels, agri-inputs, food additives, animal feed and renewable plastics, although it is not clear to what scale biofuel is being produced and the focus of the company appears to be agri-inputs (www.sea6energy.com). A number of pilot projects are currently underway which will provide further detail on the potential for macro-algae to be used in biofuels, but additionally in chemicals and food additives. These include the Sea Gas Project (www.seagas.co.uk), MacroFuels (www.macrofuels.eu), the MacroBioCrude Consortium (community.dur.ac.uk/p.w.dyer/page2/styled-2/index.html) and various projects at the Scottish Association for Marine Science (www.sams.ac.uk) including the BioMara project (www.biomara.org). Each of these pilot projects has been focused predominantly on the technical aspects of biofuel production from macro-algae and have begun to make significant strides in this area. However, there are numerous factors which appear to be acting to slow the commercialization 
of technologies including immature technology and a lack of infrastructure meaning that macro-algae biofuel may yet not be ready for widespread commercialization.

A useful tool to assess the steps involved in bringing plant-based feedstocks to market for aviation biofuels is the Feedstock Readiness Level (FSRL) tool which was developed by the US Department of Agriculture, US Federal Aviation Administration and Research and Innovative Technology Administration [19]. The tool allows comparison between different alternative fuels and how their development may be facilitated or constrained by feedstock availability and supply chain development [19]. The tool is comprised of four components which impact the commercialization of any feedstock from (1) production, through (2) market and (3) policy to (4) linkage to the conversion process; within this, feedstocks pass through nine levels from (1) basic principles to (9) production capacity established [19]. The Feedstock Readiness Level (FSRL) is useful here to assess the further development stages which will be needed to bring the use of macro-algae to maturity and further commercialization [19]. There is uncertainty as to which FSRL stage macro-algae biofuel technology research has reached, but current projects via a range of technologies appear to have demonstrated the basic principles (level 1), concept formulation (level 2) and proof of concept (level 3) (see technical section below). Apart from a few isolated projects away from the UK (www.sea6energy.com), primarily technical evaluation appears to be taking place (level 4) as well as process validation (level 5) in the pilot projects noted above. Current research needs to take macro-algae biofuel production to levels 6 (full-scale technical evaluation) and in some cases 7 (certification/fuel approval), although it is noted that there are a range of technical challenges and uncertainties (e.g., environmental impacts, technology choice, algae productivity, etc.) associated with large-scale algae biofuel production [12]. This will then lay the path for levels 8 (commercialization) and 9 (production capacity established). It is suggested that algae biofuels could be both technically and economically viable within the next ten to twenty years [12] but that commercialization in the UK is far from being realized.

However, this paper is not primarily concerned with technological aspects of macro-algae but is more focused on the policy, economic and wider social impacts of macro-algae biofuel production. As noted as part of the Feedstock Readiness Tool (FSRL) [19] it is extremely important, alongside technological development of the feedstock and related processes, to identify regulatory requirements, determine the potential for societal resistance and overcome social concerns. This shows a need to go beyond technological elements of the development and look more widely at all potential stakeholders who could or will be affected by the production processes. Research notes that these types of niche technologies have been characterized by a technology push approach with the focus on R\&D. This has been without due consideration of the commercial prospects, societal embedding, legal procedures and societal stakeholders which has resulted in implementation problems [20]. However, information in these non-technology areas has not been systematically collected and there are major uncertainties surrounding the precise economic, environmental and political conditions required to support a seaweed biofuel industry within developed OECD nations.

A route cause of this lack of knowledge may be in the lack of peer-reviewed empirical studies investigating the economic, environmental, social and political issues associated with seaweed. With the exception of some limited research [16], discussing the marine policy implications for seaweed biofuels in Ireland and the UK, there are few detailed investigations into the potential socio-economic, environmental and political issues associated with what could be a hugely beneficial technology $[16,21]$. This is particularly strange considering that there are a large number of government and grey-literature studies, as well as increasing academic interest and papers which have investigated the impacts of seaweed cultivation in areas where seaweed cultivation and farming has been popular for the food and cosmetic industries [22]. Research suggests that although Atlantic species of macro-algae are likely to be smaller than those utilized in the Pacific there is potential for large scale cultivation in the European temperate waters which would cover waters from northern Portugal to northern Norway [23]. A significant number of these studies can be found within Food and Agriculture Organisation reports including Food and Agriculture Organisation (FAO) (2006) and numerous industry investigations into 
using seaweed dating to as early as the 1970s [14]. Indeed, over 23 million dry tons of macro-algae were produced by aquaculture in 2012, mostly for human consumption [24]. For biofuel stakeholders and policy makers to fully understand the issues related to developing a seaweed biofuel industry, it is necessary to provide an in-depth and robust review of the seaweed literature beyond technological aspects. Extant studies which have investigated seaweed cultivation for food and cosmetics within Asian regions can provide vital information about the potential economic, environmental and political issues of seaweed biofuels. Indeed, these issues are well investigated with regards to conventional biofuels [9] and other renewable technologies (in particular wind) and it is sensible to draw on this and related literatures to compare and contrast the potential issues for seaweed as has been done in the investigation of the emergence, development and uptake of aviation biofuels [2].

Hence this paper, drawing on multiple related literatures, seeks to provide an as comprehensive as is possible picture of the economic, and environmental, social and policy issues related to the current situation and future potential development of seaweed biofuels in the UK. This paper therefore draws on grey and online literature sources as well as peer-reviewed academic publications. We also draw on publications regarding the seaweed industry in Asia and again acknowledge that the conclusions of these papers and reports may not always be relevant in the UK (which we highlight at relevant points throughout the paper). To gain a broad picture beyond technological aspects the paper will follow from the tradition of macro-environmental scanning [25]. Environmental scanning developed as it was suggested that any organizational or industry success is based on how well they respond to macro social, economic, technological or political/regulatory changes [26]. Scanning of the macro-environment allows organisations to identify issues most likely to impact them so they can be prepared to cope with any issues or opportunities as they arise [26]. A macro-environmental scan should be systematic and proactively examine emerging threats and opportunities as they arise $[25,26]$. It is the first step in any strategic planning and is vital in emerging industries [27]. It has been used previously to assess several energy sectors including liquid biofuel policy [27] and bio-coal [28]. The paper will, in particular, use a PESTEL (political, economic, social-cultural, technological, environmental and legal) framework [29]. Due to the lack of literature in the area the political and legal aspects will be assessed together. Technological aspects, as the most developed, but not core to the aims of this paper will be discussed first. The issues will be analysed within the context of the established biofuels industry as well as being contrasted with other renewable energy technologies. As will be seen, although the technology is not yet advanced, it is vital to have a clear understanding of the potential social, economic and political aspects of its development to ensure a proactive approach to the multiple stakeholders who will need to support its continued development. Finally, the paper will make recommendations for a future research agenda and make potential UK specific policy implications to support the on-going emergence, development and uptake of seaweed biofuel technology within the UK.

\section{Technological Issues}

As noted above, the focus of this paper is not technological development or a review of this aspect, but an overview of the technological aspects is included here for readers not familiar with macro-algae biofuels and to provide background to the other features discussed below. This section is not exhaustive and readers who would like to learn more about the technological aspects should see the various papers noted within this section for more detail.

The term biofuel refers to any form of renewable energy that is derived from biomass, i.e., plants, vegetation or animal matter (OECD, 2010). There are two basic forms of biofuel; primary biofuel and secondary biofuel. Primary biofuels are the most basic form of bioenergy and require no additional processing; these fuels include fire wood, wood chippings and agricultural waste. Primary biofuels are mainly used for domestic heating applications and electricity production. Indeed, they represent by far the largest share of bioenergy globally $(\sim 80 \%)$ and they are still the main energy source of domestic energy for developing countries [12]. It is calculated that primary biofuels account for around $8 \%$ of 
total global energy demands (OECD, 2010). The other form of biofuel is secondary biofuel which is made from biomass that has undergone some form of processing to change the chemical composition of the original material [6]. The processing could be in the form of fermentation to ethanol, mechanical pressing and extraction of oils, anaerobic digestion of the biomass to produce methane, and could involve a number of complex chemical processes [30]. Depending on the type of processing used the resultant biofuel will either be in a solid, liquid or gaseous form.

Macro-algae biofuels, as noted in the introduction are a secondary biofuel and would be likely to be used predominantly as liquid transport fuel. In liquid form, biofuels such as ethanol and biodiesel are predominantly used in the transportation industry to replace petrol and diesel. These fuels represent around 3\% of the global total bioenergy mix and approximately $0.3 \%$ of global energy demands [31]. Liquid biofuels are by far the fastest growing bioenergy sector in the world due to strong government incentives to increase production in several OECD countries, as well as increased demand from the transportation sector. Liquid biofuel production is forecast to grow between 6-8\% per annum until 2030 [31]. To cope with this high rate of growth, the biofuel industry and governments are constantly exploring new biofuel feedstocks, processing technologies and policy mechanisms in order to ensure that future expansion is achievable and sustainable.

In comparison to micro-algae, macro-algae have had very little attention and investment from the biofuel industry. This is even though studies $[17,18]$ indicate that seaweed shows potential as a biofuel feedstock for countries with abundant coastlines such as the UK and has significant potential as a feedstock. Macro-algae are marine photosynthetic organisms commonly referred to as seaweed. They can be loosely categorised into green (Chlorophyceae), brown (Phaeophyceae) and red (Rhodophyceae) varieties. Depending on their specific type, seaweed can be consumed as food or processed into a variety of products including animal feeds, food additives, cosmetics, chemicals, medicines and biofuels [32]. The market for seaweed has grown substantially in the last 30 years, increasing from 4 million wet tonnes in 1980 to around 20 million wet tonnes in 2010 [33]. A significant proportion of this recent increase has come from the expansion of the food market which has included red seaweeds which can be used to make thickening agents for the processed foodstuff industry [34]. Asia is the largest market for seaweed, consuming around $83-90 \%$ of the global total [35]. The estimated global value of the seaweed industry is around US\$5-6 billion [32,33]. Although there are several applications for seaweed, using it to generate fuel has thus far had very little traction in the biofuels industry. This is despite the fact that seaweed has an advantage compared to land based biofuel feedstocks [17], it typically grows faster than land based crops and it is capable of being cultivated in a number of different climates $[17,35]$. Seaweed also grows in marine environments so it avoids the issues associated with land-use change and competition with traditional food crops [35].

Over the last 30 years there have been a number of research projects that have investigated the potential of using macro-algae to produce biofuels $[18,36]$ exploring some of the secondary biofuel technologies, cultivation and production processes available. These have included studies in the UK, Ireland, Japan, Korea, the Philippines, Vietnam, Chile and China [14] with macro-algae biofuels under investigation including the production of methane [37], ethanol [38], biodiesel and more recently, aviation biofuel. In the UK, brown algae have been identified as having the greatest potential for bioconversion to energy as they are often found in colder waters [39]. Additionally, the majority of biomass comes from a relatively small number of species in the orders Laminariales and Fucales with subtidal large brown kelps of the order Laminariales thought to have the most potential [39]. Particular species that have been suggested for biofuel production and have been successfully grown and harvested include Gelidium amansii, Laminaria japonica, Laminaria saccharina, Sargassum fulvellum, Sargassum naozhouense, Saccharina latissimi, Palmaria palmata, Ulva lactuca and Ulva pertusa amongst others $[15,39,40]$. Some of the earliest investigations were conducted as part of the US Ocean Food and Energy Farm project [41] and the Marine Biomass Program [42]. These programs investigated the potential of cultivating seaweed off-shore to produce methane in anaerobic digesters. The investigation revealed that anaerobic digestion of the seaweed was technically feasible, however; technical issues 
were encountered during the cultivation of the seaweed in open ocean environments [17] and it was suggested that no cost-effective means of growing the seaweed in off-shore environments could be found at that time [42]. In Europe, one of the earliest reported macro-algae biofuel research initiatives was the COST (European Cooperation in Science and Technology) 48 programme initiated in approximately 1985 and was funded until approximately 1994. The programme led to a wide range of workshops and visits to promote communication and co-operation between researchers on macro-algae projects as wide ranging as biomass conversion, seaweed fermentation, proteins, outdoor seaweed cultivation and seaweed cellular biotechnology [43]. While this project may have kickstarted a number of projects in the area there are very few specific outputs from the project [43].

More recently the technological processes of developing biofuels from macro-algae have increasingly been discussed and more robustly examined showing further continued interest in the area. There is now considerable clarity over the different macroalgal production process that are necessary (cultivation, harvesting, post-harvest treatments (including cleaning, size reduction, preservation and storage) and energy extraction) [44]. In addition, there is now considerable detail regarding the different energy extraction methods which are available for macro-algae which differ based on whether dry or wet macro-algae are used in the process. These include direct combustion, pyrolysis, gasification and trans-esterification to biodiesel for dry macro-algae [44,45]. For wet macro-algae they include hydrothermal treatments, fermentation to bioethanol or biobutanol and anaerobic digestion [44]. The paper "Macroalgae-Derived Biofuel: A Review of Methods of Energy Extraction from Seaweed Biomass" [44] provides an overview of the different methods of energy extraction making comparisons between them for readers who are interested in the technological aspects which are not the focus of this paper. Additionally, further research has increased our understanding of the various aspects of using seaweed as a potential biofuel examining issues such as ensilage, anaerobic digestion and slow pyrolysis [46-48], beach seaweed [49], dewatering treatments [44,50], potential products from seaweed [51], and a range of process hurdles [52].

Despite the fact that there has been a significant increase in the number of initiatives in recent years commercial outputs from the initiatives have been limited, particularly within the EU [14]. This is despite private investment and collaboration from major oil producers including BP, Shell, Statoil and Exxon Mobil [14]. Indeed, despite 30 years of interest in macro-algae biofuels, production processes are still in their very early stages of development [14]. Furthermore, designs for seaweed hatcheries and grow-out facilities are untested on large scales $[36,53]$ and methods of storage and energy balances of various biofuel processing techniques remain unclear [37].

\section{Economic Issues}

The most basic economic issue is that a renewable technology must be economically viable and be economically positive to the region and country in which it is situated. Economic viability at the most basic level for the organisation will be determined by the technological development and commercialisation of the product itself and as commercialisation is not currently close it may be a while before any certainty about this element can be sought. One of the only investigations into the economic viability of macro-algae biofuels [16] investigated the Irish and UK marine management issues associated with macro-algae cultivation and found that there was scepticism of the economic viability of farming seaweed in offshore locations but supported the development of inshore cultivation. In addition, issues have been raised by some seaweed farmers who suggest that the prices of seaweed may be too low to generate worthwhile profit [54]. Specific techno-economical assessments were published in 2012 and 2013 [35,37]. The first of these assessments [35], focused on the US, notes that "the resource potential of macroalgae as an energy feedstock is considered to exceed that of all terrestrial biomass by about three-fold" (page 36) but that the costs are currently uncertain as this is likely to depend heavily on where and how the biofuel is produced and the economic feasibility of the production and conversation processes. The second techno-economic assessment in 2013 [37] focused on Europe, anaerobic digestion integrated with a biogas fired combined heat and power (CHP) unit 
and on Laminaria digitate. The calculations made were based on a number of assumptions such as feedstock prices, DCF (Discounted Cash Flow) rates and operating costs which suggested a potential breakeven electricity selling price of $€ 120 / \mathrm{MWh}$. Additionally, they note that more systematic studies are required to understand potential investment decisions and future financial risks (for example through increasing feedstock prices as feedstock cost is the most significant cost) [37]. Additional research on marine biomass also suggests that the financial viability of this is extremely sensitive to the input price of the feedstock, at least for anaerobic digestion [55]. Research also highlights the potential extra costs around the supply of fresh water for production and suggests an additional extra cost could be the necessity for desalination units [37].

In terms of wider economic issues, a number of studies have explored this element within Asia and Europe, although once again these studies have focused on the cultivation and farming aspects. In Asia where the seaweed industry has grown rapidly in recent years [32], a number of local economies producing seaweed (including Indonesia, Philippines, India, Chile, United Republic of Tanzania and the Solomon Islands) have been positively transformed [14]. Indeed, studies suggest that in Asia the overall economic impact of the seaweed industry has been positive [34]. With the exception of Japan, seaweed farming in Asia is labour intensive and almost every stage of the farming process is carried out by hand. According to research [54], 84 person-days ( $8 \mathrm{~h}$ days) are required to generate one tonne of dry seaweed. This is providing coastal communities in seaweed-producing nations with regular and stable employment [34] mostly via seasonal employment and is transforming many traditional fishing communities which were previously in decline due to over-fishing [56]. The incomes which can be generated from the seaweed industry are also significant. Part-time seaweed farmers can generate annual incomes of between US $\$ 5000$ to US $\$ 20,000$, while full-time workers with larger commitments are known to have made up to three times as much in Indonesia [56]. These incomes have brought seaweed farmers well above global poverty levels in countries such as Indonesia [56]. As well as direct employment in farming activities, the seaweed industry supports many trading, administration, laboratory and government office jobs [57]. In the Philippines, it is estimated that the seaweed industry supports around 100,000-150,000 farm workers, 30,000-50,000 local consolidators and 20,000 small seaweed traders [57].

However, the situation in Europe is quite different, and the literature focused on Asia may not be relevant to the UK. Although the European seaweed industry is currently profitable and despite a long history of seaweed harvesting in Europe, production has dropped by a third from 350,000 tons to around 231,000 tons per year since the year 2000 [58]. Research in Norway suggests that seaweed farming can have negative impacts for other industries and that the harvesting of wild seaweed has reduced local fish catches costing around one million pounds a year (15M NOK) [59]. It is suggested that this is caused by significant losses of grazing sea urchins [59], and is therefore also an environmental impact (which will be discussed further below). In addition, unlike in Asia, seaweed farming and harvesting is not a significant employer and most commercial jobs are seasonal [34]. In France and Spain, seaweed harvesters are legally categorised as 'fishers' and can gain access to health insurance, pension and social benefits. However, because the work is seasonal, they also have a specialised fisheries social security fund that they pay into each month. In Norway, most seaweed workers are employed by the seaweed processing industries and have access to normal social benefits [58] but other seaweed workers in Norway are self-employed and registered as 'fishers'.

As well as the commercial seaweed industry within Europe, there is also a limited amount of seaweed which is gathered by coastal communities such as in the Basque country, Cantabria and Galicia [47]. These operations are invariably undeclared and use immigrant workers which are not officially employed in the country, thus taking money away from local communities and may represent a negative economic impact. Similar actions of collecting seaweed by coastal communities take place on small scales in some Irish [58] and Scottish communities [60]. In Scotland beach-cast seaweed is sometimes collected by crofters to use as fertiliser and it is noted that if seaweed becomes a regular feedstock for biofuels this availability for crofters should be protected [60]. 
However, recent work has suggested that if a seaweed biofuel industry could be commercialised, beyond farming and aquaculture, this could foster economic development, job and income generation, especially in rural areas [5,12]. It is noted [12] that algae biofuels, as an industry have the potential to provide a range of high and low skill jobs and that "employment rates of bioenergy per MWh are higher compared to fossil fuel supplies" [61] (455p). This is however only the case if any use of seaweed applies sustainable methods and levels of harvest [60]. Additionally, a UK government report in 2010 highlights that the development of bioenergy may be constrained by lack of confidence in supply chains and markets and commercial operations may be unwilling to scale up their operations unless there is clear demand for the resulting products [45].

From an economic perspective, it is clear that the profitability and wider effects of regional development and job creation are very much dependent on the future commercialisation of the technology and the relevant supply chains that are developed around production and processing facilities. It also seems likely that whether the facilities for aquaculture are off shore, or in shore, will be an important indicator of employment prospects and seasonal employment may also play an important role in the likely regional economic impact of this renewable technology. However, as these details are presently uncertain the economic influence, either positive or negative, is largely unknown.

\section{Social Issues}

Research on the social impacts of the seaweed and macro-algae biofuel industry are limited and again focus on the early cultivation and production farming stages and provide only a flavour of the potential social impacts, either negative and positive, from the development of a UK based macro-algae biofuel supply chain.

The majority of work that indicates potential social issues has been based on the Asian seaweed farming industry. This work highlights the industries effects on social equality in some areas as a significant proportion of jobs are filled by women [62] in Asia and India which has resulted in stable incomes and safe working environments [33,62]. Women are also transitioning into playing a leading role in seaweed farming within the United Republic of Tanzania [54]. However, this is not the case in all regions and in the Solomon Islands and Indonesia the majority of work is carried out by men [34]. The resulting increase in incomes has been shown to allow children to continue in schooling in Indonesia [34], but in the Solomon Islands this had had the opposite effect as children have been encouraged to become farmers [63]. Further social impacts have been improvements in housing and purchasing assets [54] in the United Republic of Tanzania and increased employment levels in coastal communities in South Africa [64]. As well as impacts on incomes and education, there is considerable evidence which suggests that seaweed farming has led to improvements in the quality of life in coastal communities such as participation in leisure activities (Indonesia) and religious pilgrimage (India) [56] and well as an increase in community cohesion (Solomon Islands) [63].

However, these types of social impacts have not been studied within the European context and little is known about the potential social impacts of both seaweed farming and wider macro-algae biofuel development in the UK and whether the above impacts on society, family incomes, schooling, etc., would translate to the UK market. However, research on the social impacts of other renewable technologies are more detailed and could shed light on some potential issues for macro-algae biofuel development in the UK.

Opposite to the work discussing the impact of seaweed farming above, much of the work looking at the societal impacts of renewable technologies in the UK shows a more negative effect on society and it is accepted that public acceptance and a positive perception of renewables is important for a successful energy transition to renewable sources [65]. While general opinion surveys often show support for renewable energy projects, this does not always translate to local acceptance and does not consider any other necessary infrastructure that may need to be put into place [66]. Work highlights the effect that forceful local opposition and resistance has had on the development of wind and solar farms $[61,65,66]$ which has run from passive opposition to fierce confrontation and 
legal action [61]. It has been suggested that the social acceptance of renewable technologies was ignored in favour of a focus on technology aspects, which in turn led to major opposition in the development of both wind and biomass [20]. This opposition has been based on negative perceptions of particular developments with opposing parties raising potential issues of emissions, bad smells, visual appearance/impact (greater for onshore and close to shore wind developments), traffic congestion and diminished recreational value, aesthetics, property, health and safety concerns [61,67], damage to marine life, aesthetics and impact on boating/fishing/recreational activities [68,69]. These perceptions are also likely to be accentuated if the individual is not familiar with the technology (as is likely to be the case with macro-algae biofuels) and where they feel powerless to affect the implementation in their neighbourhoods [61]. Additionally, it has been found that doubts about the environmental and social sustainability of feedstock for bioenergy supply may further critically increase the resistance by both local residents and also NGOs [61].

However, not all perceptions are negative and work also shows that individuals perceive the social benefits of job creation, energy security and social and economic development through direct and indirect employment which may lead them to support developments $[8,61]$ as well as a desire overall for energy security/independence [68]. Areas around the north-west of Scotland have been highlighted as particularly suitable for macro-algae production, at least in part due to the existing skill base in this area [45].

A number of studies, particularly looking at on- and off-shore wind developments and solar developments have also looked at individual and community aspects which are likely to affect the response to various types of developments. Work suggests that those individuals who are younger, have a higher level of education and own their own home are more likely to be supportive of wind farms [69] and those who are closer to sites of implementation are more likely to be dissatisfied and less supportive of the projects [65]. Additionally, the siting of windfarms seems to be a key factor with more positive attitudes towards offshore wind farms that onshore wind farms [67]. It is also suggested, for the impact of offshore wind, that the level of resistance will be determined by how frequently individuals use beaches and for what type of activity (and therefore how likely they are to see and come into contact with developments) [70]. Level of place attachment and relationships with developers and outsiders have also been noted as key factors affecting acceptance [71-73]. These issues are also likely to be of relevance to any seaweed farming aspects.

Overall the research highlights that to overcome any potential resistance from local communities there must be trust building transparency, two-way communication and knowledge transfer to create understanding of the benefits of biofuels in the early stages of planning [61]. The transfer of correct knowledge is of vital importance because research has suggested that the perceptions on which opinions are based often appear to be factually incorrect [69]. Additionally, knowledge or awareness levels of renewable energy are generally low [61]. This is especially the case where local communities are likely to feel powerless about the implementation of the technology in their locality [61]. It is also suggested that the public should be included in decision-making with both on- and off-shore developments [71].

Given the uncertainty over the potential production and processes both in terms of aquaculture and supply chain elements for macro-algae biofuels it is hard to predict whether the social concerns and potential opposition would materialise. However, the key message is that any development in this area must be preceded by a proactive understanding of the potential for these types of issues and concerns. It seems likely that similar concerns would be raised as for biomass and onshore wind but each renewable technology and its related processes is different and only further research will be able to shed light on this further and give a more concrete understanding.

\section{Environmental Issues}

It is of vital importance to understand the potential environmental impacts of macro-algae biofuel at all stages of its cultivation and production, especially where this might be doubly affected by a negative response from individuals also resulting in social impacts. Other renewable technologies 
have been criticised for their environmental impacts often resulting in negative media coverage, interrupting the commercialisation and widespread acceptance of these technologies. For example, biofuels more widely have been criticised for potential problems with acidification, ecological toxicity etc. and competition between agricultural land use (which is not an issue for aquaculture specifically) and water shortage [50,61]. The issue of seasonal availability has also been noted [61] and potential impacts on biodiversity protection which might be of relevance to macro-algae biofuels [8].

While environmental impacts of macro-algae biofuel production have been suggested in a number of studies these are not well understood, as with many of the issues already discussed, these concentrate on the farming and cultivation of seaweed and do not take into account potential public reactions to these environmental issues. Studies which have explored environmental impacts beyond Europe have suggested both positive and negative impacts on the coastal environments. Positive impacts include improvements in the benthic ecosystem, increased carbon seeking and the conservation of local marine habitats. Anecdotal evidence from India [33], the Philippines [57], and the Solomon Islands [63] suggest that fisheries which were previously in decline have seen an improvement in fish stocks. Negative impacts such as the effect of invasive species on marine ecosystems are commonly mentioned however there is little supporting evidence to suggest that this is actually happening in Asian regions [34,62]. Researchers warn however that it is essential that the introduction of seaweed to marine environments includes quarantine and protocols [74] to protect against ecosystem damage. Also, the introduction of seaweed in Indonesia has had impacts on the benthic ecosystem by changing the sea floor habitat, however, this could potentially be because of wooden stakes, anchors and equipment from the farming techniques used rather than the seaweed itself [56].

The effect on local marine habitats and the potential for invasive species need to be understood with the UK/Europe. Within Europe however, research in Norway and Scotland has focused on the environmental impact of harvesting wild or beach-cast seaweed $[60,75]$ rather than cultivation of seaweed. The research reveals that although only $0.3 \%$ of Norway's natural seaweed stock is harvested, this can represent up to $50 \%$ of the natural seaweed biomass in some marine environments. Removing this much seaweed biomass could have significant environmental impacts [75] and it takes approximately five years for the seaweed to be naturally replaced and seven years before biodiversity is fully restored [76]. Some research also notes the benefits of leaving algae on beaches to provide a growth medium for foreshore development and as a source of food for birds and therefore any exploitation of beach cast seaweed should consider potential impacts in this way [60]. Additionally, some beds of seaweed (e.g., kelp beds west of the Uists) are thought to provide coastal protection and carefully management is therefore needed [60]. It is also suggested that for small scale seaweed harvesting the method of harvesting and the size and rotation of harvest is important to ensure that seaweed populations and biodiversity is retained [60]. The most sensitive harvesting technique is considered cutting rather than pulling and research favours smaller areas and shorter rotations over harvesting larger areas on a long rotation [60]. With sensitive harvesting, it has been suggested that around the coast of Scotland (in particular around the Western Isles) there are $1000 \mathrm{~km}^{2}$ of seaweed habitats that provide sufficient densities for commercial harvest [55].

It is also suggested that there are a number of significant unknowns with regards to the potential environmental impacts of seaweed farming [77]. These unknowns can be grouped into three main elements of uncertainty: (1) effects on the physical environment (e.g., on current speed, light penetration etc.); (2) dissolved nutrient dynamics in and around the farm (e.g., competition with natural populations of algae and competition between and within adjacent farmers); (3) effects on marine life (e.g., plankton, benthos, fish, marine mammals and seabirds) [77]. It has also been highlighted that even if local species of seaweed are used to avoid invasion of non-native species, the cultivation of seaweed at a large level might provide a source for new mutants [15]. Finally, it has also been suggested that the potential environmental impacts of transportation between cultivation and processing sites and post-processing needs to be taken into account in any environmental assessment [16]. 
One positive impact is that seaweed farming does not use fertilisers and there is also some research to suggest that macro-algae can clean waters by purifying polluted water by the removal of nutrients [40,78] avoiding eutrophication in seas and oceans [15]. It is also suggested that these characteristics do not interfere within its feasibility as a feedstock for biofuel production [79].

The potential scale of a seaweed industry the UK would also need to be taken into account when considering the environmental impacts. According to research [21] developing a macro-algae biofuel industry will require volumes of seaweed on a scale of millions of tonnes. This would require thousands of square kilometres of sea area. This will impact coastal communities and visitors to coastal communities and may generate negative public perceptions of the industry. While there is no public perception research that has assessed the potential reaction, it is clear that this may be important as in Norway there are internet articles, Facebook groups and action groups that show a level of public resistance to the harvesting of Norwegian seaweed (Stopptt.no, 2014). This again shows the strong linkage between environmental and social issues which may affect the development of a macro-algae biofuels supply chain.

One potential way to mitigate some potential environmental issues and also to ensure that aquaculture and farming relating to seaweed may gain less social opposition is by using co-location of marine activities [80]. Research suggests that as there is increasingly conflict between marine activities, marine protected areas and users (as noted in the social issues section, e.g., boating and recreation), offshore aquaculture, locating seaweed farming with offshore wind farms is becoming increasingly attractive [80]. It is suggested that this approach is technologically and scientifically feasible, and could reduce start-up costs [80]. However, as not even any pilot studies have been initiated there is a need to consider incentives for offshore wind operators and the feasibility of farming in this environment [80].

Once again, although technological development is slowly taking place, there is a little certainty over the potential environmental impacts, especially once a process is scaled up, from macro-algae aquaculture in the UK. From a strategic planning perspective, the impact of this is perhaps most important from a social concerns viewpoint. This again highlights the importance of a pro-active approach to working with residents, communities and other potential stakeholders.

\section{Political and Legal Issues}

Political and legal issues related to the potential development of macro-algae biofuels are not widely discussed in the academic or non-academic literature. Biofuel expansion in the last 50 years has been driven primary by energy policy in the form of subsidies, mandates, blending targets and/or tax relief/exceptions for the fuel $[5,6]$ and it is reasonable to assume that energy policy will play an equally important role in the future expansion of seaweed biofuels and indeed that promotion of biofuels is needed through government policy [5]. Research suggests that a mix of government initiatives is likely to work best in reducing risk for investors and shows that both capital grants and subsidies complement one another [81]. It has been highlighted that feed-in-tariffs or renewable obligation certificates could improve the economic viability of any project [37]. Although investment in renewables has increased significantly to US $\$ 285.9$ bn ( $£ 202.3 \mathrm{bn})$ in 2015 [82], the government still has an important role in facilitating investment to make it easier for projects to secure funding [81]. Indeed, much research shows that the stability and consistency of government policy, especially within changing political environments, with regards any renewable technology can greatly affect the level of investment in renewables $[8,20,83,84]$.

Similarly, for legal issues there is very little work and little agreement with some authors suggesting that legislative restrictions are a challenge for UK macro-algae biofuel [16] while others suggest that the legislative environment for macro-algae cultivation is actually relatively open [17], using the rapid expansion of new aquiculture sites in Scotland to present their point.

As with the other dimensions highlighted above the available and relevant research is based on the early cultivation and farming stages of a seaweed and not beyond. In Asia seaweed farming is actively supported through government funding, development agencies, NGOs and research communities [34]. However, regulation in most Asian countries, apart from Japan, is limited [12]. Seaweed farming is 
sometimes included with fishery licences, and under national fisheries policies [34]. However, in other regions including the United Republic of Tanzania, no formal regulation of seaweed is provided and there are no licences required to farm seaweed because existing regulation on aquatic flora does not include seaweed [54]. From an Asian perspective, with the exception of Japan, the main governance mechanism has been the open market [56]. This has led to a series of negative issues, mainly ecological, highlighting potential for further environmental issues. Evidence from the FAO research reveals that in periods of highly volatile market conditions, farmers cut as much seaweed as is physically possible without any consideration for the ecological impacts that it might create [56]. In other situations, when the price has dropped dramatically, the seaweed farms have little choice but to sell their products at low prices because there are no government regulations on sale prices [56].

In Europe, the seaweed industry is more heavily regulated, though it varies considerably between countries [58] and many of the above issues are unlikely to be relevant. The biggest difference is between Northern Europe and Southern Europe. In Southern European countries including France, Portugal and Spain, the use of the foreshore coastal areas is regulated by the state and the use of the space is up to public authorities [58]. In Spain, the first eight nautical miles from the shore are under the responsibility of the local fisheries administration while the zone between 8-12 miles is under state administration. In Portugal, the fisheries authorities have complete control of the zone out to 12 nautical miles. In Northern Europe however, marine areas can be under the responsibility of the state, the crown estate in the case of the UK, or local landowners [58]. This could create more issues associated with conflicted interests [16] and requires further analysis. To set up a seaweed farm in the UK a lease is required to use the seabed and a marine license is needed from the national regulator [77]. It is suggested that clarity about the procedure, for macro-algae in particular, over the level of assessment required for the marine licensing processes is needed [77].

As noted previously, with only a growing understanding of the potential processes and production for macro-algae biofuels it is likely that government policy may not be doing much to support this development. Therefore, potential producers and academics involved in these developmental studies must be in contact with government to ensure a suitable policy framework is developed to support this industry.

\section{Future Research Agenda and Implications for Policy}

It is clear that technological and scaling up issues are still limiting the development of biofuels from macro-algae and that this dimension is the most important in determining the likely success and financial viability of macro-algae biofuels. Research in this area is well underway but will require continued funding to succeed. Indeed, research [16] suggests that the technical and economic issues associated with the development of a macro-algae supply chain could be quickly overcome if additional research and funding were made available. However, supporting macro-algae cultivation through government funding is associated with a significantly high levels of risk due to uncertain environmental impacts, the potential to create stakeholder conflicts and the uncertainty surrounding the public perception of macro-algae biofuels. Indeed, if the development of macro-algae is to be supported, there must be careful consideration made toward the method and scale of support provided. Biofuel policy support has been crucial for the initial stages of biofuel technology development [9], however, in some situations, policy support can lead to the rapid expansion of environmentally unsustainable fuels [6] as occurred within the U.S. corn ethanol industry where the use of subsidies to support the expansion of that industry was hugely successful in expanding production but there was a lack of understanding surrounding the economic and environmental impacts of supporting ethanol production This eventually led to the reduction of subsidies for corn ethanol. To support the development of an emerging biofuel technology in a sustainable manner, particularly with the case of macro-algae, policy support must be carefully considered. In addition, research [84] highlights the need for stability and longevity in any government financial support for renewables technologies but 
also that there is little agreement in the industry over the use of subsidies. Clarity of guidance is also required for successful applications for marine licenses for seaweed farming [77].

An additional difficulty arises when considering the fact that much of the UK marine environment could be considered a common good which is used by multiple stakeholders and restricting access to certain areas of the sea may create stakeholder conflicts and create problems in marine spatial planning [80]. Indeed, research [16] warns of the potential conflicts between marine stakeholders and the threat this poses for expansion is significant. This highlights the lack of knowledge in this area, and a lack of understanding of the viewpoints of stakeholders, whether marine users, fishers or local residents and how they might respond to the development of macro-algae biofuels. As is clear in the sections outlined above, the potential for social concerns and active opposition, whether related to seasonal work, impact on communities, environmental issues and general public acceptance [65] must be researched urgently to allow a proactive and transparent development of this technology and supply chain. It has been suggested that a deeper understanding of people's mental representations of renewable technology is important in determining how people will judge it and should therefore be a focus for future research [65]. Additionally, general public surveys will not be enough to capture stakeholder's views. While these are commonly used to assess public opinion, and often report positive results with regards to renewable technologies, it is important that these research opportunities are used to assess reactions on a concrete level highlighting specific challenges and drawbacks [65]. This full stakeholder approach has been highlighted as important in previous work $[5,61]$, which notes that a detailed evaluation of the supply chain, including all stakeholders, is necessary. This will highlight the management challenges and opportunities clearly and allow the future business to run effectively and efficiently within a supportive policy environment.

Additionally, as has been continually highlighted, much of the research in this area is not UK specific and focuses only on the cultivation and farming stages of the biofuel development process. Research notes that due to the many gaps in understanding an overly conservative approach might be taken to monitoring which might put off investors, in turn damaging a potentially positive industry from developing [77]. Future research must focus on the UK and must go beyond the early stages of the supply chain. It must examine all stakeholders throughout the process, from seaweed farmers to the end consumers of transport fuels. Any policy decisions by government and practical economic decisions made by companies wishing to commercialize technologies must be made in light of an understanding of all stakeholders' perceptions and likely responses. Additionally, it must not be so conservative as to halt development of the industry if it can be sustainably developed.

This work has initiated an initial scan of the macro-environmental factors and as development happens continual monitoring and future forecasting of the various macro-environmental factors must take place to ensure continued competitive advantage [26]. However, it has been difficult to disentangle the various PESTEL elements and each in turn may have a knock-on effect on each other so any future research must examine all elements for all stakeholders to further understand this complex web of perceptions and requirements.

\section{Final Remarks}

Environmental scanning is the first step in the development of strategy and provides vital information for objective setting, resource allocation and systematic strategic planning [25-27]. The review highlights that due to the relative technological infancy of the macro-algae biofuel industry and a lack of understanding of many of the issues which are relevant, the environmental scan has many informational gaps which will need to be filled. Additionally, we had to draw on both online only and grey literature sources alongside academic peer reviewed papers to provide a comprehensive picture and acknowledge that some of these sources may be less reliable. Overall it is also clear that a proactive approach is needed in researching each of these areas and ensuring that research is represented further in peer reviewed academic journals. It is also clear that early and open contact with 
a range of stakeholders including government is also required. Without this, a macro-algae biofuel supply chain is likely to meet significant and unknown societal resistance.

Acknowledgments: This research was funded by the EPSRC (project EP/KO14900/1: MacroBioCrude) and this funding also covered the cost for open access publishing.

Conflicts of Interest: The authors declare no conflict of interest. The founding sponsors had no role in the design of the study; in the collection, analyses, or interpretation of data; in the writing of the manuscript, and in the decision to publish the results.

\section{References}

1. Searchinger, T.; Heimlich, R.; Houghton, R.A.; Dong, F.; Elobeid, A.; Fabiosa, J.; Yu, T.H. Use of US croplands for biofuels increases greenhouse gases through emissions from land-use change. Science 2008, 319, 1238-1240. [CrossRef] [PubMed]

2. Gegg, P.K. Factors Affecting the Emergence, Development and Uptake of Aviation Biofuels. Ph.D. Thesis, Loughborough University, Loughborough, UK, 2014. Available online: https:/ /dspace.lboro.ac.uk/dspacejspui/handle/2134/14074 (accessed on 20 December 2013).

3. Bryne, J.; Lund, D. Clean energy transition-Our urgent challenge: An editorial assey. WIREs Energy Environ. 2017, 6, e243. [CrossRef]

4. Zhao, B. Why will dominant alternative transportation fuels be liquid fuels, not electricity or hydrogen? Energy Policy 2017, 108, 712-714. [CrossRef]

5. Chanthawong, A.; Dhakal, S. Stakeholders' perceptions on challenges and opportunities for biodiesel and bioethanol policy developments in Thailand. Energy Policy 2016, 91, 189-206. [CrossRef]

6. Worldwatch Institute. Biofuels for Transport: Global Potential and Implications for Sustainable Energy and Agriculture; Earthscan: London, UK, 2009.

7. De Jong, S.; Antonissen, K.; Hoefnagels, R.; Lonza, L.; Wang, M.; Faaij, A.; Junginger, M. Life-cycle analysis of greenhouse gas emissions from renewable jet fuel production. Biotechnol. Biofuels 2017, 10, 62. [CrossRef] [PubMed]

8. McGrath, J.F.; Goss, K.F.; Brown, M.W.; Bartle, J.R.; Abadi, A. Aviation biofuel from integrated woody biomass in southern Australia. WIREs Energy Environ. 2016, 6. [CrossRef]

9. Gegg, P.; Budd, L.; Ison, S. The market development of aviation biofuel: Drivers and constraints. J. Air Transp. Manag. 2014, 39, 34-40. [CrossRef]

10. Hill, J.; Nelson, E.; Tilman, D.; Polasky, S.; Tiffany, D. Environmental, economic, and energetic costs and benefits of biodiesel and ethanol biofuels. Proc. Natl. Acad. Sci. USA 2006, 103, 11206-11210. [CrossRef] [PubMed]

11. Gallager, E. The Gallagher Review of the Indirect Effects of Biofuels Production; Renewable Fuels Agency: St Leonards -on-sea, UK, 2008.

12. Naik, S.N.; Goud, V.V.; Rout, P.K.; Dalai, A.K. Production of first and second generation biofuels: A comprehensive review. Renew. Sustain. Energy Rev. 2010, 14, 578-597. [CrossRef]

13. Adenle, A.A.; Haslam, G.E.; Lee, L. Global assessment of research and development for algae biofuel production and its potential role for sustainable development in developing countries. Energy Policy 2013, 61, 182-195. [CrossRef]

14. James, M.A. A Review of Initiatives and Related RED Undertaken in the UK and Internationally Regarding the Use of Macroalgae as a Basis for Biofuel Production and Other Non-Food Use Relevant to Scotland; Marine Scotland: Edinburgh, Scotland, 2010. Available online: http://www.scotland.gov.uk/Topics/marine/ science/Publications/publicationslatest/planning/MacroalgaeReport1 (accessed on 20 December 2013).

15. Fernand, F.; Isreal, A.; Skjermo, J.; Wichard, T.; Timmermans, K.R.; Golberg, A. Offshore macroalgae biomass for bioenergy production: Environmental aspects, technological achievements and challenges. Renew. Sustain. Energy Rev. 2017, 75, 35-45. [CrossRef]

16. Roberts, T.; Upham, P. Prospects for the use of macro-algae for fuel in Ireland and the UK: An overview of marine management issues. Mar. Policy 2012, 36, 1047-1053. [CrossRef] 
17. Hughes, A.D.; Black, K.D.; Campbell, I.; Heymans, J.J.; Orr, K.K.; Stanley, M.S.; Kelly, M.S. Comments on 'prospects for the use of macroalgae for fuel in Ireland and UK: An overview of marine management issues'. Mar. Policy 2013, 38, 554-556. [CrossRef]

18. Watson, L.; Dring, M. Business Plan for the Establishment of a Seaweed Hatchery and Grow-Out Farm; Irish Sea Fisheries Board (BIM): Dublin, Ireland, 2011. Available online: http:/ /www.bim.ie/media/bim/content/ publications / Business,Plan, fot, the,Establishment, of, a, Seaweed,Hatchery, and, Grow-out,Farm.pdf (accessed on 28 July 2017).

19. Steiner, J.J.; Lewis, K.C.; Baumes, H.S.; Brown, N.L. A Feedstock Readiness Level Tool to Complement the Aviation Industry Fuel Readiness Level Tool. BioEnergy Res. 2012, 5, 492-503. [CrossRef]

20. Verbong, G.; Geels, F.W.; Raven, R. Multi-niche analysis of dynamics and policies in Dutch renewable energy innovation journeys (1970-2006): Hype-cycles, closed networks and technology-focused learning. Technol. Anal. Strateg. Manag. 2008, 20, 555-573. [CrossRef]

21. Burton, T.; Lyons, H.; Lerat, Y.; Stanley, M.; Rasmussen, M.B. A Review of the Potential of Marine Algae as a Source of Biofuel in Ireland; Sustainable Energy Authority of Ireland: Dublin, Ireland, 2009.

22. Werner, A.; Clarke, D.; Kraan, S. Strategic Review of the Feasibility of Seaweed Aquaculture in Ireland; NDP Marine RTDI Desk Study Series DK/01/008; Marine Institute: Parkmore, Ireland, 2004.

23. Kraan, S. Mass-cultivation of carbohydrate rich macroalgae, a possible solution for sustainable biofuel production. Mitig. Adapt. Strateg. Global Chang. 2013, 18, 27-46. [CrossRef]

24. Loureiro, R.; Gachon, C.M.M.; Rebours, C. Seaweed cultivation: Potential and challenges of crop domestication at an unpredicted pace. New Phytol. 2015, 206, 489-492. [CrossRef] [PubMed]

25. Costa, J. An empirically-based review of the concept of environmental scanning. Int. J. Contemp. Hosp. Manag. 1995, 7, 4-9. [CrossRef]

26. Ginter, P.M.; Duncan, W.J. Macroenvironmetal Analyses for Strategic Management. Long Range Plan. 1990, 23, 91-100. [CrossRef]

27. Talamini, E.; Wubben, E.F.M.; Padula, A.D.; Dewes, H. Scanning the macro-environment for liquid biofuels: A comparative analysis from public policies in Brazil, United States and Germany. J. Strategy Manag. 2013, 6, 40-60. [CrossRef]

28. Wang, L.; Lurina, M.; Hyytiäinen, J.; Mikkonen, E. Bio-coal market study: Macro and micro-environment of the bio-coal business in Finland. Biomass Bioenerg. 2014, 63, 198-209. [CrossRef]

29. Walsh, P.R. Dealing with the uncertainties of environmental change by adding scenario planning to the strategy reformulation equation. Manag. Decis. 2005, 43, 113-122. [CrossRef]

30. Ragauskas, A.J.; Williams, C.K.; Davison, B.H.; Britovsek, G.; Cairney, J.; Eckert, C.A.; Frederick, W.J.; Hallett, J.P.; Leak, D.J.; Liotta, C.L.; et al. The Path Forward for Biofuels and Biomaterials. Science 2006, 311, 484-489. [CrossRef] [PubMed]

31. International Energy Agency. Sustainable Production of Second-Generation Biofuels: Potential and Perspectives in Major Economies and Developing Countries; IEA: Paris, France, 2010. Available online: https:/ / www.iea.org/ publications/freepublications/publication/second_generation_biofuels.pdf (accessed on 22 June 2017).

32. McHugh, D.J. A Guide to the Seaweed Industry; Food and Agriculture Organization of the United Nations: Rome, Italy, 2003.

33. Krishnan, M.; Narayanakumar, R. Social and economic dimensions of carrageenan seaweed farming in India. In Social and Economic Dimensions of Carrageenan Seaweed Farming; Fisheries and Aquaculture Technical Paper No. 580; Valderrama, D., Cai, J., Hishamunda, N., Ridler, N., Eds.; FAO: Rome, Italy, 2013; pp. 163-185.

34. Valderrama, D.; Cai, J.; Hishamunda, N.; Ridler, N. (Eds.) Social and Economic Dimensions of Carrageenan Seaweed Farming; Fisheries and Aquaculture Technical Paper No. 580; FAO: Rome, Italy, 2013; 204 p.

35. Roesijadi, G.; Jones, S.B.; Snowden-Swan, L.J.; Zhu, Y. Macroalgae as a Biomass Feedstock: A Preliminary Analysis; Pacific Northwest National Laboratory: Richland, WA, USA, 2010. Available online: https:/ /www.pnl.gov/ main/publications/external/technical_reports/PNNL-19944.pdf (accessed on 18 July 2017).

36. Edwards, M.; Watson, L. Aquaculture Explained: Culivating Laminaria Digata; Irish Sea Fisheries Board (BIM): Dublin, Ireland, 2011. Available online: http:/ /www.bim.ie/media/bim/content/publications / BIM\%20Aquaculture\%20Explained\%20Issue \%2026\%20-\%20Cultivating\%20Laminaria\%20digitata.pdf (accessed on 20 December 2013). 
37. Dave, A.; Huang, Y.; Rezvani, S.; McIlveen-Wright, D.; Novaes, M.; Hewitt, N. Techno-economic assessment of biofuel development by anaerobic digestion of European marine cold-water seaweeds. Bioresour. Technol. 2013, 135, 120-127. [CrossRef] [PubMed]

38. Horn, S.J.; Aasen, I.M.; Ostgaard, K. Ethanol Production from Seaweed Extract. J. Ind. Microbiol. Biotechnol. 2000, 25, 249-254. [CrossRef]

39. Murphy, F.; Devlin, G.; Deverell, R.; McDonnell, K. Biofuel Production in Ireland-An Approach to 2020 Targets with a Focus on Algal Biomass. Energies 2013, 6, 6391-6412. [CrossRef]

40. Tsagkamilis, P.; Danielidis, D.; Dring, M.J.; Katsaros, C. Removal of phosphate by the green seaweed Ulva lactuca in a small-scale sewage treatment plant (Ios Island, Aegean Sea, Greece). J. Appl. Phycol. 2010, 22, 331-339. [CrossRef]

41. Wilcox, H.A. The U.S. Navy's Ocean food and energy farm project. In Ocean Energy Resources; Proceedings of the Energy Technology Conference, Houston, Tex., 18-23 September 1977; American Society of Mechanical Engineers: New York, NY, USA, 1977; pp. 83-104.

42. Bird, K.T.; Benson, P.H. Seaweed Cultivation for Renewable Resources; Elsevier Science Ltd.: Amsterdam, The Netherlands, 1987.

43. Kain, J.M. News from Europe. Eur. J. Phycol. 1993, 28, 197-198. [CrossRef]

44. Milledge, J.J.; Smith, B.; Dyer, P.W.; Harvey, P.J. Macroalgae-Derived Biofuel: A Review of Methods of Energy Extraction from Seaweed Biomass. Energies 2014, 7, 7194-7222. [CrossRef]

45. Government of the United Kingdom. 2050 Pathways Analysis; Department of Energy and Climate Change: Aberdeen, UK, 2010. Available online: https://www.gov.uk//government/uploads/system/uploads/ attachment_data/file/42562/216-2050-pathways-analysis-report.pdf (accessed on 23 July 2017).

46. Milledge, J.J.; Staples, A.; Harvey, P.J. Slow Pyrolysis as a Method for the Destruction of Japanese Wireweed, Sargassum muticum. Environ. Nat. Resour. Res. 2015, 5, 28-36. [CrossRef]

47. Redden, H.; Milledge, J.J.; Greenwell, H.C.; Dyer, P.W.; Harvey, P.J. Changes in higher heating value and ash content of seaweed during ensiling. J. Appl. Phycol. 2016, 1-10. [CrossRef]

48. Milledge, J.J.; Harvey, P.J. Potential process 'hurdles' in the use of macroalgae as feedstock for biofuel production in the British Isles. J. Chem. Technol. Biotechnol. 2016, 91, 2221-2234. [CrossRef] [PubMed]

49. Milledge, J.J.; Harvey, P.J. Golden Tides: Problem or Golden Opportunity? The Valorisation of Sargassum from Beach Inundations. J. Mar. Sci. Eng. 2016, 4, 60. [CrossRef]

50. Gallagher, J.A.; Turner, L.B.; Adams, J.M.M.; Dyer, P.W.; Theodorou, M.K. Dewatering treatments to increase dru matter content of the brown seaweed, kelp (Laminaria digitata ((Hudson) JV Lamouroux)). Bioresour. Technol. 2017, 224, 662-669. [CrossRef] [PubMed]

51. Milledge, J.J.; Neilson, B.V.; Bailey, D. High-value products from macroalgae: The potential uses of the invasive brown seaweed, Sargassum muticum. Rev. Environ. Sci. Bio/Technol. 2015, 15, 67-88. [CrossRef]

52. Milledge, J.J.; Harvey, P.J. Ensilage and anaerobic digestion of Sargassum muticum. J. Appl. Phycol. 2016, 28, 3021-3030. [CrossRef]

53. Stévant, P.; Rebours, C.; Chapman, A. Seaweed aquaculture in Norway: Recent industrial developments and future perspectives. Aquac. Int. 2017, 1-18. [CrossRef]

54. Msuya, F.E. Social and economic dimensions of carrageenan seaweed farming in the United Republic of Tanzania. In Social and Economic Dimensions of Carrageenan Seaweed Farming; Fisheries and Aquaculture Technical Paper No. 580; Valderrama, D., Cai, J., Hishamunda, N., Ridler, N., Eds.; FAO: Rome, Italy, 2013; pp. 115-146.

55. Hermannsson, K.; Swales, K. Financial viability of energy from marine biomass: Re-examination of the evidence. Int. J. Ambient Energy 2015, 36, 253-261. [CrossRef]

56. Neish, I.C. Social and economic dimensions of carrageenan seaweed farming in Indonesia. In Social and Economic Dimensions of Carrageenan Seaweed Farming; Fisheries and Aquaculture Technical Paper No. 580; Valderrama, D., Cai, J., Hishamunda, N., Ridler, N., Eds.; FAO: Rome, Italy, 2013; pp. 61-89.

57. Hurtado, A.Q. Social and economic dimensions of carrageenan seaweed farming in the Philippines. In Social and Economic Dimensions of Carrageenan Seaweed Farming; Fisheries and Aquaculture Technical Paper No. 580; Valderrama, D., Cai, J., Hishamunda, N., Ridler, N., Eds.; FAO: Rome, Italy, 2013; pp. 91-113.

58. Netalgae. Seaweed Industry in Europe. 2012. Available online: http://www.netalgae.eu/uploadedfiles/ Filieres_12p_UK.pdf (accessed on 22 June 2017). 
59. Sakshaug, E.; Dale, T.; Fosså, J.H.; Fredriksen, S.; Hedlund, N.; Sivertsen, K. Nedbeiting av tareskog i Norge. MareNor. 2002. Available online: https:/ / www.regjeringen.no/globalassets/upload/kilde/fid/rap/2002/ 0008/ddd/pdfv/158055-nedbeiting_tareskog02.pdf (accessed on 28 July 2017).

60. Angus, S. Modern Seaweed Harvesting and Gathering in Scotland: The Legal and Ecological Context. Scott. Geogr. J. 2017, 133, 101-114. [CrossRef]

61. Gold, S. Bio-energy supply chains and stakeholders. Mitig. Adapt. Strateg. Glob. Chang. 2011, 16, 439-462. [CrossRef]

62. Ramachandran, C. "A Sea of One's Own!" A perspective on gendered political ecology in Indian mariculture. J. Asian Fish. Soc. 2012, 25S, 1-12.

63. Kronen, M. Social and economic dimensions of carrageenan seaweed farming in the Solomon Islands. In Social and Economic Dimensions of Carrageenan Seaweed Farming; Fisheries and Aquaculture Technical Paper No. 580; Valderrama, D., Cai, J., Hishamunda, N., Ridler, N., Eds.; FAO: Rome, Italy, 2013; pp. 147-161.

64. Troell, M.; Robertson-Andersson, D.; Anderson, R.J.; Bolton, J.J.; Maveldt, G.; Halling, C.; Probyn, T. Abalone farming in South Africa: An overview with perspectives on kelp resources, abalone feed, potential for on-farm seaweed production and socio-economic importance. Aquaculture 2006, 257, 266-281. [CrossRef]

65. Sútterlin, B.; Siegrist, M. Public acceptance of renewable energy technologies from an abstract versus concrete perspective and the positive imagery of solar power. Energy Policy 2017, 106, 356-366. [CrossRef]

66. Bidwell, D. The role of values in public beliefs and attitudes towards commercial wind energy. Energy Policy 2013, 58, 189-199. [CrossRef]

67. Ladenburg, J.; Sanja Lutzeyer, A. The economics of visual disamenity reductions of offshore wind farms-Review and suggestions from an emerging field. Renew. Sustain. Energy Rev. 2011, 16, 6793-6802. [CrossRef]

68. Firestone, J.; Kempton, W.; Lilley, M.B.; Samoteskul, K. Public acceptance of offshore wind power across regions and through time. J. Environ. Plan. Manag. 2012, 55, 1369-1386. [CrossRef]

69. Firestone, J.; Kempton, W. Public Opinion about Large Offshore Wind Power: Underlying Factors. Energy Policy 2007, 35, 1584-1598. [CrossRef]

70. Ladenburg, J. Attitudes towards offshore wind farms-The role of beach visits on attitude and demographic and attitude relations. Energy Policy 2010, 38, 297-1304. [CrossRef]

71. Haggett, C. Understanding public responses to offshore wind power. Energy Policy 2011, 503-510. [CrossRef]

72. Gifford, R.; Nilsson, A. Personal and social factors that influence pro-environmental concern and behavior: A review. Int. J. Psychol. 2014, 49, 141-157. [CrossRef] [PubMed]

73. Bang, H.-K.; Ellinger, A.E.; Hadjimarcou, J.; Traichal, P.A. Consumer concern, knowledge, belief and attitude toward renewable energy: An application of the Reasoned Action Theory. Psychol. Mark. 2000, 17, 449-468. [CrossRef]

74. Sulu, R.; Kumar, L.; Hay, C.; Pickering, T. Kappaphycus Seaweed in the Pacific: Review of Introductions and Field Tasting Proposed Quarantine Protocols; Secretariat of the Pacific Community: Noumea, New Caledonia, 2004.

75. Steen, H. Stortare. In Kyst og Havbruk; Institute of Marine Research: Bergen, Norway, 2009; pp. 211-214.

76. Waage-Nielsen, E.; Christie, H.; Rinde, E. Short-term dispersal of kelp fauna to cleared (kelp-harvested) areas. Hydrobiologia 2003, 503, 77-91. [CrossRef]

77. Wood, D.; Capuzzo, E.; Kirby, D.; Mooney-McAuley, K.; Kerrison, P. UK macroalgae aquaculture: What are the key environmental and licensing considerations? Mar. Policy 2017, 83, 29-39. [CrossRef]

78. Haglund, K.; Lingström, K. The potential use of macroalgae for removal of nutrients from sewage water in East Africa. Ambio 1995, 24, 510-512.

79. Ge, S.; Champagne, P. Cultivation of the Marine Macroalgae Chaetomorpha linum in Municipal Wastewater for Nutrient Recovery and Biomass Production. Environ. Sci. Technol. 2017, 51, 3558-3566. [CrossRef] [PubMed]

80. Christie, N.; Smyth, K.; Barnes, R.; Elliott, M. Co-location of activities and designations: A means of solving or creating problems in marine spatial planning? Mar. Policy 2013, 43, 254-261. [CrossRef]

81. Leach, A.; Doucet, J.; Nickel, T. Renewable fuels: Policy effectiveness and project risk. Energy Policy 2011, 39, 4007-4015. [CrossRef]

82. Kinver, M. UN: 2015 Record Year for Global Renewables Investment. BBC News Online. Available online: www.bbc.co.uk/news/science-environment-35891876 (accessed on 24 March 2016). 
83. Geels, F.W. Editorial: The dynamics of sustainable innovation journeys. Technol. Anal. Strateg. Manag. 2008, 20, 521-536. [CrossRef]

84. Wells, V.K.; Greenwell, E.F.; Covey, J.; Rosenthal, H.; Adcock, M.; Gregory-Smith, D. An exploratory investigation of barriers and enablers affecting investment in renewable companies and technologies in the UK. J. R. Soc. Interface Focus 2013, 3. [CrossRef] [PubMed] 